\title{
Libya: \\ Arms Proliferation and Armed Groups. The Libyan Conflict Revisited
}

\author{
Felix SHIHUNDU
}

\begin{abstract}
The study critically analyses the effects of the Libyan arms proliferation, with a focus on the Small Arms and Light Weapons (SALW) in the region. It traces the proliferation of arms occasioned by the Civil War in Libya and establishes an empirical link to some of the regional security challenges to the proliferation. Relevant theoretical perspectives, such as the Security Dilemma and the Security Complex Theory, are adopted to explain the resulting effects of the proliferation such as the increased deadly violence of the rebel forces in the region and the neighboring Middle East region. Innovative arms control has been presented as the opportunity for the region to address the security challenges which are quickly evolving into a proliferation of advanced sophisticated weapons, some of them in the rebel-controlled territories. The study concludes that the regional security challenges partly originate from the Libyan arms proliferation which have also worsened security challenges in different parts of the world.
\end{abstract}

Keywords: Arms proliferation, Security Dilemma, Libya, Regional Security Complex, arms control, Disarmament, Demobilization and Re-integration.

\section{Introduction}

The consequences of arms proliferation are more pronounced in Africa compared to the other regions. More than a half of the countries in the continent have experienced armed conflicts that can be linked directly to arms proliferation albeit at varying degrees. Africa has been a theatre for international great power rivalry either directly or through proxies, armed rebel groups, mercenaries, as well as organized criminal
Felix SHIHUNDU

Department of International Relations

Ankara Social Sciences University, Turkey

Email: shihundufelix@gmail.com

Conflict Studies Quarterly

Issue 38, January 2022, pp. 60-72

DOI: $10.24193 /$ csq.38.4

Published First Online: 05 January / 2022 
gangs. Efforts towards arms control have registered little success with conflicts protracting with devastating effects.

There is no agreed definition of small arms and this study adopts the definition set by the 1997 UN Panel of Governmental Experts on Small Arms which considers portability of both weapons as a defining characteristic. Some of the weapons include revolvers and self-loading pistols, rifles and carbines, sub-machine guns and assault rifles, and light machine guns and their ammunition. Small arms are both durable and portable. They are mobile and relatively easy to conceal, making them easy to trade, move, hide or steal. Small arms are light and easy to use even by children (United Nations Security Council [UNSC], 1997).

\section{Understanding the Gap}

The fall of the Gaddafi regime in Libya has witnessed increased armed rivalry and tensions in the neighboring countries and almost all of them have been entangled in one way or another in the Libyan Crisis with no end in sight. A significant number of the neighboring states across three continents in Africa, Middle East and Europe have plunged into direct or proxy conflicts which can be argued to be directly linked to the arms proliferation occasioned by the dismantling of the central holding authority in Libya. Libya, as a country, was believed to possess enormous amount of stockpiles of weaponry and it was in the process of developing biological, chemical and nuclear armaments although with great difficulties as a result of the increased pressure from the international community led by the United States. The main argument of the study is that the crisis facing the neighboring regional states is a result of the dangerous proliferation of arms from the national stores of the fallen Gaddafi regime in Libya. The study critically analyses the consequences of arms proliferation as a result of the Libyan Crisis and provides suggestions for the actors involved to move towards a legitimate arms control regime in a region that has quickly transformed into a proliferation arena for technologically advanced sophisticated arms. The arms control mechanism has the potential of stabilizing the region, first by denying the rebels ammunition for attacking civilians and threatening governments, especially in the Sahel region, and secondly by restoring trust and confidence to the arms suppliers that no actor will be capable of threatening vital interests from Libya.

The study reviews both primary and secondary empirical evidence from published sources such as journal articles, books, relevant government records, records from relevant international organizations such as the United Nations Security Council meetings and resolution on the conflict, with the objective of finding out the effects of the Libyan arms proliferation to the region. The Libyan Crisis is used as a case study to comprehensively review the impacts of arms proliferation and to suggest a legitimate all-encompassing arms control regime that has remained a pipe dream in many re- 
gions engulfed in armed conflicts. The qualitative data is utilized to give meaning to observations and events critically analyzed. The outcomes of the study are considered useful to the actors involved in the conflict directly and indirectly, the international organizations that are working towards a solution to the challenges of Libya and, most importantly, the people of Libya and all those who are victims of arms in the wrong hands longing for justice.

The study approaches the issue of arms proliferation through the lens of the Security Dilemma Theory and the Regional Security Complex Theory. According to the Security Dilemma, one party's security concerns, sometimes necessitated by the anarchic international order, prompts an overall diminishing in security of the others, leading them to also increase their security and this unresolvable uncertainty increases arms to unprecedented levels (Roe, 1999). At the intrastate level, the disintegrating state and ethnic hostilities may aggravate the situation, motivating armed groups to exploit each other's relative weakness in an attempt to fill the power vacuum created by the crumbling state (Jeong, 2008). The rival groups are in the same dilemma as states in the international system, characterized by fear, uncertainty and urgent need to increase own security (Hill, 2005). Acquisition of arms is a key factor of the security dilemma and arms control is a solution to it. Arms control potentially reduce the hostility caused by the security dilemma, providing an opportunity for cooperation (Wendt, 1992).

The Regional Security Complex Theory holds that proximity is a source of security concerns and security threats most probably take place within the region. Regional actors interact with the security of the other actors in the region resulting into a security interdependence. The Security Complex Theory links internal conditions in states, relations among states in the region, relations among regions, and relations between regions and globally acting great powers (Buzan et al., 1998, p. 11).

\section{Brief Literature Review}

Small arms are responsible for more casualties than any other type of weapon, they aggravate conflicts, destabilize societies and hinder development. Proliferation has been defined as the spread of weapons from one group to another. Variations include vertical proliferation, which involves spread among different actors within a state, and lateral proliferation, where the acquisition involves a spread to other states (Sokolski etal., 2014).

The control of small arms and light weapons, including their ammunition, is a key element of crisis prevention and post-conflict peacebuilding in the field of conventional arms control. Security is crucial for development and the proliferation of arms hinders economic and social development and plays a major role in the violent escalation of conflicts. For instance, shoulder-fired anti-aircraft systems, or "Man-Portable Air-Defense 
Systems" ("MANPADS"), which are regarded as light weapons, represent a serious threat to both civilian and military aircrafts.

In Africa, some of the regional initiatives towards arms control include the Declaration of a Moratorium on Importation, Exportation and Manufacture of Light Weapons in West Africa (1998), the Southern African Development Community (SADC) Protocol on the Control of Firearms, Ammunition and Other Related Materials (2001) and the Nairobi Protocol for the Prevention, Control and Reduction of Small Arms and Light Weapons in the Great Lakes Region and the Horn of Africa (2004). Others include the peace and security agenda of the New Economic Partnership for Africa's Development (NEPAD) and the African Union (AU).

According to Bolton et al, (2012), proliferation of arms is facilitated by certain intermediaries based on legal or illegal demands coming from particular lawless or restricted environments. The United Nations, in 2001, aimed to counter proliferation of small arms through the legally binding Protocol on Firearms to the Vienna Convention against Transnational Organized Crime and the Program of Action (PoA) to prevent, combat and eradicate the illicit trade in small arms and light weapons (United Nations General Assembly [UNGA], 2001), as well as the subsequent adoption of the International Tracing Instrument to enable states to identify and trace illicit small arms and light weapons. The Program of Action contains statements and recommendations on various aspects of small arms control laws, production, marking and registration, cooperation on tracing, storage, destruction of surplus arms, awareness-raising among the population, disarmament, demobilization and reintegration, as well as international trade and has been the launch-pad for a host of global and regional initiatives to help states implement it and to find the broadest possible consensus on the most important elements (United Nations Security Council [UNSC], 2001).

Also, a report of the UN panel of Government Experts on Small Arms states, in section 36 that, "mere accumulation of weapons is not sufficient criterion ... to define an accumulation of weapons as destabilizing, since large numbers of weapons that are under the strict control of a responsible state do not necessarily lead to violence. Conversely, a small number of weapons can be destabilizing under certain conditions" (United Nations Office for Disarmament Affairs, 2000). On nuclear weapons, the General Assembly, in order to mobilize international efforts towards achieving a nuclear weapon free world, declared 26 September as the International Day for the Total Elimination of Nuclear Weapons in resolution 68/32 of 5 December 2013.

Arms control, at the national level, aims at creating oversight of weapon possession and use and may include the prevention of possession of certain types of weapons either among the general public or restricted access to individuals who are presumed high-risk amongst the population. At the international level, arms control has developed through legal and political agreements aimed at regulating the production, trade, use, distribu- 
tion, handling and disposal of arms. Arms embargoes are illustrations of international attempts to restrict access to arms of certain high-risk actors by separating legitimate from illegitimate holders of the means of violence. Arms control, however, is unlikely to lead to social justice; instead, it contributes to negative peace (Galtung, 1969).

\section{Libya Arms Regime. A Brief Overview}

Gaddafi amassed an enormous collection of military hardware during his decades in power, providing training, supplies and arms in Sierra Leone, Janjaweed forces in Darfur and invading neighboring Chad. He also created the Islamic Legion mercenary army to fulfill his vision of a pan-Arabic band across North Africa. Gaddafi purchased arms worth billions of dollars since 1969 fueled by massive oil reserves. From 1970 until 2009, and even with a long-term UN arms embargo in place between 1992 and 2003, Libya spent around \$30bn on weapons, mostly from USSR. Much of the weaponry and ammunition originated from Eastern Europe and Russia. France and Germany earned \$3.2bn and $\$ 1.4$ bn respectively from arms deals with the Libyan regime (Feinstein, 2011).

On December 19, 2003, Muammar Gaddafi welcomed international inspectors to verify Tripoli's commitment to Non-Proliferation Treaty (NPT), following allegations of owning Weapons of Mass Destruction (WMD). Inspectors from the United States (US), United Kingdom (UK) and international organizations worked to dismantle Libya's chemical and nuclear weapons programs, as well as its long-range ballistic missiles. Normalization of relations with US, which was cut off in 1981, was considered. The US invasion of Iraq, an interdiction of a ship containing nuclear-related components destined for Libya, as well as sanctions and diplomatic efforts, are believed to be among the factors leading to Tripoli's decision.

UN Security Council adopted Resolution 748 of 1992 imposing sanctions on Libya, including an arms embargo and air travel restrictions. In 2004, the EU lifted the arms embargo on Libya, allowing EU countries to export to Libya arms and other military equipment. The reasoning was to improve Libya's capacity to patrol its maritime borders and prevent migration to the EU from North Africa which was a great concern to Southern European states such as Italy. European arms transfers are governed by the EU's Code of Conduct on Arms Exports and national export control laws. In 2011, UNSC Resolution 1973 authorized an international response to the Libyan civil war. The resolution created a no-fly zone over Libya, strengthened arms embargo and inspection of suspected weapons trafficking ships and planes traveling to the country.

\section{Analyzing the Regional Effects of the Libyan Arms Proliferation}

Libya enjoys a geo-strategic location in the African continent with strong Arab ties to the Middle East. The country is separated from Europe and the Middle East only by the Mediterranean Sea. This regional proximity makes it possible for the neighboring states 
to experience increased security threats and other related shocks due to the ongoing civil war and the weak administration in the country.

The first report by the UNSC group of experts monitoring Libyan arms embargo, at the start of the uprising in 2011, recognized that Libya was a key source of weapons in the region due government struggles to exert authority as former rebel fighters clench power on the ground. According to the report, "illicit transfers from Libya in violation of the embargo cover more than 12 countries and include heavy and light weapons, including man-portable air defense systems, small arms and related ammunition and explosives and mines" (UNSC, 2013).

The number of countries increased to at least 14 countries on several continents in the following year, according to Rwandan ambassador Eugene Gasana, then chair of the UN. Security Council's Libya Sanctions Committee (UNSC, 2014a). According to his report, non-state armed actors-controlled the majority of stockpiles in Libya and ineffectual border control systems made the country a primary source of illicit weapons, including MANPADs. The proliferation is fueling conflicts in Africa and the Levant by enriching the arsenals of the non-state actors. It also has a dimension on the existing tensions amongst EU member states, especially NATO allies, on the enforcement of the sanctioned regime and the arms embargo.

The transfers of arms to Syria from Misrata and Benghazi in Libya via northern Lebanon has resulted in the loss of many innocent lives and displacement of many. Syria demonstrates that continued availability of arms supply can delay and disrupt post-conflict reconstruction efforts and fuel insecurity and instability over the long-term. Studies have shown that the transfer of weapons is more likely to cause conflicts to escalate because, unlike looted weapons, transferred weapons are more likely to be integrated into rebel fighting doctrines and structures which is the final phase of weapons acquisition (Bourne, 2007). Moore (2012) observes that the international transfer of arms represents a unique form of foreign policy that is not explained by intervention framework alone since not all transfers are interventions.

Armed insurgencies acquire weapons through four main ways. They begin with readily available weapons, then to the previous leftovers, into the primary source of rebel arming which is stealing from government sources as a result of their increased capacity (Jackson, 2010). Lastly, acquisition of weapons from international suppliers, including gray and black-market transfers which have greater effects on the civil war. International supplies escalate the conflict and expand weapons access that would otherwise be unavailable domestically. Rebels can obtain training from state suppliers to better use their weapons or tactics manuals and peer mentoring from similar grouping elsewhere. International sources represent a transition from low-level insurgency to the internationalization of the conflict (Marsh, 2007). 
The UN report also identified the trafficking from Libya to Egypt which is a challenge primarily for Egypt's internal security in relation to armed groups in the Sinai. However, some of the material crossed Egypt to further destinations, including the Gaza Strip, which borders Israel. The armed groups in the Gaza Strip are able to purchase new weapons, including more modern assault rifles and anti-tank weapon systems (Nichols, 2013). The weapons are also believed to be stockpiled by Egyptian Salafi groups and in the Sinai Peninsula which is already unstable. This provides a challenge to the magnitude of the security dilemma to Egypt to maintain a military advantage over the Gaza rebels as well as the source country Libya. Egypt seized small, light and heavy weapons systems, ammunition for heavy weapons systems and ammunition for small arms and machine guns. Effective Egyptian response to the arms flows in the Sinai is also hampered by the 1979 Egypt-Israel Peace Treaty which imposed restrictions on Egypt's deployment of the military in Sinai.

The dangers of not arming are unbearable for the state of Egypt with the reality of more superior weapons in the neighborhood. Egypt, therefore, engages in the endless arms race as a basic option for acquiring the military capabilities required to achieve international goals and gain allies. It is believed to be acting rationally as the causes are external and the arming has no consequences of its own (Glaser, 2000). However, Egypt may also be acting sub-optimally building up arms because the domestic interests have distorted its policy. Arming due to distorted internal circumstances, such as the inherent fear of a coup d'état or a significant disruption from some internal elements and factions, is likely to produce negative consequences.

The arms were also transported through Southern Tunisia, Southern Algeria and Northern Niger to destinations such as Mali. Terrorists, criminals and drug trafficking networks with links to the wider Sahel region have cropped up in the transit areas. In Mali, weapons from Libya helped a rebel coalition topple the democratically elected government in Bamako in May 2012 and allowed a jihadist alliance to gain control over the country's Northeast with the al-Qaeda-linked groups enjoying weapons, fighters and cash from Libya. The Tuareg fighters that had served as mercenaries in Libya remained armed after the fall of Gaddafi (Patrick \& Bennett, 2013).

The Libyan conflict has also brought into sharp focus the European Union's (EU's) unity and role in monitoring compliance with the UN sanctions regime in Libya. Proposed naval missions in the Mediterranean, like Sophia, are limited since potential arms embargo violators, like the neighboring Egypt, for instance, can access Libya by means of land (Rettman, 2011, 2020; Council of the European Union, 2011). The French were the biggest EU arms suppliers to foreign protagonists in the Libya war. The others, like Germany, Italy, Spain, Sweden and UK, granted permits for more than €1 bn of arms to UN sanctions violators, such as Egypt and the UAE (UNSC, 2019). France granted permits worth €14.1bn for arms deals with Egypt in 2018, 
$€ 9.5 \mathrm{bn}$ for the UAE and €295m to Libya. Other EU states did the same under a UN aegis in 2018, including Italy (€4.1m of armored vehicles and explosive devices), Germany (€2.3m of vehicles) and the UK (€0.3m of explosives and electronics) (Council of the European Union, 2019).

The EU and NATO, at large, are engrossed in realpolitik and arms proliferation in a geopolitical conflict involving Turkey and Russia. France arms engagement has been influenced by the desire and capacity to penetrate Africa, to impose set of values, imaginations and practices deemed to be superior (Slater, 2004). The French considers actors in Africa as in need of progress, reform or order. It is constituted by lack of respect, belittling of the differences and intrinsic value of African society. The clash with Turkey on Libya's arms control can be explained by the thinking and believe that non-European or Western states cannot play a lead role in enforcing arms control regimes and in international security at large.

According to a report released by UN experts, Qatar and the United Arab Emirates (UAE) breached the arms embargo on Libya by providing weapons and ammunition with some reports of direct involvement in the conflict through air strikes (Lederer, 2020; Bakir, 2020). Power struggle and the quest for regional dominance has inspired the two states to actively pursue proliferation of weapons to an end, as deduced from Hobbesian perspectives.

During the 2012-2014 period, weapons of Libyan origin were reportedly trafficked to the Central African Republic, Algeria, Somalia, Chad, Niger and Sudan (UNSC, 2014b). In the Horn of Africa, ammunition from Libya was found in Somalia where al-Shabab militants are still fighting the government. Algeria experienced in 2013 an attack against the Tigantourine natural gas facility in Amenas orchestrated by militants associated with an offshoot of al-Qaeda's North African affiliate, al-Qaeda in the Islamic Maghreb (AQIM), known as al-Mulathameen. In Tunisia, refugees from Libya exchanged weapons for money at the beginning of the revolution (Kartas, 2013). Nigeria believes that radical Islamist militants affiliated with Boko Haram have been emboldened by their access to Libyan arms. In Chad, the Union of Resistance Forces (UFR), encouraged by arms from Libya, has threatened President Deby's regime despite having agreed to lay down its arms in 2010. The Tuareg-based Niger Movement for Justice (MNJ) threatened attacks on oil and uranium operations in the country for a greater share of national energy revenues. In the recent days, there are growing concerns over the advanced weapons which are within the reach of the rebels in the conflict such as the advanced Chinese-made FN-6 manportable air defense system for shooting MiG-21 jet fighter, anti-tank guided missiles, thermal sights of advanced Russian-made ATGMs for targeting and reconnaissance and US made Javelin ATGMs (Vest, 2019). 


\section{Towards a Legitimate Arms Control Regime in the Region}

According to Kartas (2013), arms control ensure weapons and ammunition are held for approved purposes by individuals and groups which, in the judgment of relevant authorities, can be trusted not to misuse them. It is a process that involves regulating manufacture, possession, securing and managing of stockpiles, controlling brokering and international transfers, recovery, collection and destruction and most importantly effective marking, tracing and record keeping.

Regional arms control is one of the means to achieve a balance of power among the nervous and suspicious neighboring actors. States adopt and implement arms control agreements under certain conditions, such as the possibility to acquire arms in the future to balance other actors power and overcome threats (Schofield, 2000). For instance, attempts to prevent Turkey from acquiring the S-400 Air Defense System (ADS) were not successful because of the threat posed by similar air defense systems owned by Greece (which Turkey seeks to balance and overcome both militarily and strategically). Both countries are very critical for the success of any regional wide arms control regime resulting from the Libyan Crisis. Security guarantees from the global powers like the UN permanent members have also registered some successes which can be improved upon. For instance, Libya was able to secure its future arms balance of power capabilities against any external nuclear or chemical weapons attack by entering into an agreement with the UK after giving away the Nuclear and Weapons of Mass Destruction (WMD) programs. The UK agreed to bring to the attention and seek the intervention of the UN Security Council on behalf of Libya in the event of a nuclear attack on Libya.

The bordering states face common threats as a result of proliferation of arms from Libya. Arms control therefore should take the form of these states coming together in an alliance to balance against the external threat they are facing. The African group has been very vocal on the need for their involvement in finding solutions for the Libyan crisis because they suffer the immediate consequences. They called for an enhanced place on the table especially during the Berlin Conference on Libya in 2020 (Wilkins, 2020). Tripoli's African neighbors efforts to seek a wider role in resolving the crisis is an attempt by Africa to balance power with respect to arms-producing states outside the region such as France, Russia and Turkey.

The failures of states to effectively manage the transnational smuggling of weapons and effectively prevent the diversion of arms from government stocks to non-state groups' calls for arms control to address this inefficiency and enhance regulations and border management. Boko Haram in Nigeria has, in several occasions, supplemented its supplies from government reserves through surprise attacks to stockpile locations. This is despite the fact that Nigeria is considered a regional power in the West African region, its effectiveness in sealing the loopholes for proliferation has been called into question. Arms control provides also an opportunity for NATO and to a large extent EU 
to salvage image following accusations of aiding the proliferation from the organization's intervention in Libya without a plan to secure the arms of the Gaddafi regime which some NATO members themselves had supplied to the regime. The EU normative power is tainted by its arming of the regime in Libya (Hansen \& Marsh, 2015).

The place of DDR in stabilization and reconstruction efforts cannot be overstated. It is central in peace, security and development of communities. DDR has transformed from being a preserve of peacekeeping to include wider peace-building activities, counterinsurgency and stability operations and in tandem with counter-terrorism and anti-crime measures (Muggah \& O'Donnell, 2015). DDR can include negotiating and implementing the terms of peace in a conflict.

\section{Conclusions}

The study has traced the effects of the Libyan arms proliferation using the international relations theories of security dilemma and regional security complex. It has reviewed several empirical sources, as well as official organizational documents like the UN reports to understand the full extent of the Libyan arms proliferation. The security impacts to the immediate neighboring states have also been explored in detail, as well endeavors towards arms control in the region. The study concludes that the conflicts and instability in the region is directly linked to the Libyan arms proliferation. Examples include the toppling of a government in Mali, attempts and threats towards government in Chad, smuggling, drug trafficking and transnational crimes in the Sahel region. Other effects include the increased severity of conflicts in Syria, Boko Haram insurgencies in Nigeria and Niger and the Al Qaeda, ISIS and Al Shabaab and affiliates in Sudan, Maghreb and Somalia. However, arms control provides a golden opportunity to the region to tackle the security challenges.

The Libyan arms proliferation will continue to cause security challenges to the region for the longest time since most of the weapons involved are small arms and light weapons with a very long lifespan and with reuse or modification potential. The security threats have evolved and recently resulted in the proliferation of sophisticated weapons towards the region further aggravating the situation. The study recommends the regional state actors to immediately come together in an alliance of peace and establish a regional arms control framework that is anchored in norms and rules to earn the trust of all the actors. Disarmament operations should be coordinated across boundaries to recover, collect and destroy the arms in the wrong hands. The UN should come in to help in the integration of the militants back into the society and subsequent post-conflict rebuilding of Libya because UN led operations will offer greater legitimacy eliminating the mistrust between governments and other groupings in the country. 


\section{References}

1. Bakir, A. (2020). The UAE's disruptive policy in Libya. Insight Turkey. Retrieved from https://www.insightturkey.com/articles/the-uaes-disruptive-policy-in-libya.

2. Buzan, B., Waever, O., \& de Wilde. J. (1998). Security: A new framework for analysis. Lynne Rienner Publishers.

3. Bolton, M., Sakamoto, E. E., \& Griffiths, H. (2012). Globalization and the Kalashnikov: Public-private networks in the trafficking and control of small arms. Global Policy, 3(3), 303-313. DOI: https://doi.org/10.1111/j.1758-5899.2011.00118.x.

4. Bourne, M. (2007). Structure and dynamic in weapons spread: The trade and proliferation of weapons in comparative perspective. In M. Bourne (Ed.), Arming Conflict: The proliferation of small arms (pp. 14-52). Palgrave Macmillan UK.

5. Council of the European Union. (2011). Twelfth Annual Report according to Article 8(2) of Council Common Position 2008/944/CFSP defining common rules governing control of exports of military technology and equipment. (2011/C 9/01), 417. Council of the European Union.

6. Council of the European Union. (2019). Twenty-First Annual Report of the Council of the European Union on the control of exports of military technology and equipment (14431/19 ADD 4). Council of the European Union.

7. Feinstein, A. (2011, October 26). Where is Gaddafi's vast arms stockpile? The Guardian. Retrievedfrom https://www.theguardian.com/world/2011/oct/26/gadaffis-arms-sto ckpile.

8. Galtung, J. (1969). Violence, peace, and peace research. Journal of Peace Research, 6(3), 167-191.

9. Glaser, C. L. (2000). The causes and consequences of arms races. Annual Review of Political Science, 3(1), 251-276. DOI: https://doi.org/10.1146/annurev.polisci.3.1.251.

10. Hansen, S. T., \& Marsh, N. (2015). Normative power and organized hypocrisy: European Union member states' arms export to Libya. European Security, 24(2), 264-286. D0I: https://doi.org/10.1080/09662839.2014.967763.

11. Hill, S. M. (2005). United Nations peacekeeping, disarmament and conflict resolution. In S. M. Hill (Ed.), United Nations disarmament processes in intra-state conflict (pp. 1-26). Palgrave Macmillan UK.

12. Jackson, T. (2010). From under their noses: Rebel groups' arms acquisition and the importance of leakages from state stockpiles. International Studies Perspectives, 11(2), 131-147.

13. Jeong, H.-W. (2008). Understanding conflict and conflict analysis. SAGE Publications.

14. Kartas, M. (2013). On the edge?: Trafficking and insecurity at the Tunisian-Libyan border. Small Arms Survey.

15. Lederer, E. M. (2020, September 9). Experts: Libya rivals UAE, Russia, Turkey violate UN embargo. Washington Post. Retrieved from https://www.washingtonpost.com/b usiness/experts-libya-rivals-uae-russia-turkey-violate-un-embargo/2020/09/09/0 e851144-f260-11ea-8025-5d3489768ac8_story.html. 
16. Marsh, N. (2007). Conflict specific capital: The role of weapons acquisition in civil war. International Studies Perspectives, 8(1), 54-72.

17. Moore, M. (2012). Selling to both sides: The effects of major conventional weapons transfers on civil war severity and duration. International Interactions, 38(3), 325-347. DOI: https://doi.org/10.1080/03050629.2012.676511.

18. Muggah, R., \& O’Donnell, C. (2015). Next generation Disarmament, Demobilization and Reintegration. Stability: International Journal of Security and Development, 4(1), Art. 30. DOI: https://doi.org/10.5334/sta.fs.

19. Nichols, M. (2013, April 9). Libya arms fueling conflicts in Syria, Mali and beyond: U.N. experts. Reuters. Retrieved from https://www.reuters.com/article/us-libya-arms-unidUSBRE93814Y20130409.

20. Patrick, S. M., \& Bennett, I. (2013, January 29). Collateral damage: How Libyan weapons fueled Mali's violence. Council on Foreign Relations. Retrieved from https://www.cfr. org/blog/collateral-damage-how-libyan-weapons-fueled-malis-violence.

21. Rettman, A. (2011, February 23). EU arms to Libya: Fresh details emerge. EUobserver. Retrieved from https://euobserver.com/news/31863.

22. Rettman, A. (2020, January 24). Why do EU arms end up in Libya despite UN ban? EUobserver. Retrieved from https://euobserver.com/foreign/147256.

23. Roe, P. (1999). The intrastate security dilemma: Ethnic conflict as a "tragedy"? Journal of Peace Research, 36(2), 183-202.

24. Schofield, J. (2000). Arms control failure and the balance of power. Canadian Journal of Political Science / Revue Canadienne de Science Politique, 33(4), 747-777.

25. Slater, D. (2004). Emerging empire and the civilizing powers of intervention. In D. Slater (Ed.), Geopolitics and the post-colonial (pp. 30-53). John Wiley \& Sons.

26. Sokolski, H., Ludes, J. M., \& Fialka, J. J. (2014). Twenty-First Century weapons proliferation: Are we ready? Routledge.

27. United Nations General Assembly (UNGA). (2001). Protocol against the illicit manufacturing of and trafficking in firearms, their parts and components and ammunition, supplementing the United Nations Convention against transnational organized crime. UN. Retrieved from https://digitallibrary.un.org/record/441498.

28. United Nations Office for Disarmament Affairs. (2000). Report of the panel of governmental experts on small arms (A/52/298). United Nations. DOI: https://doi. org/10.18356/7dfd781a-en.

29. United Nations Security Council (UNSC). (1997). Report of the Panel of Governmental Experts on Small Arms (UN Documents: Security Council Report A/52/298; p. 37). United Nations. https://www.securitycouncilreport.org/un-documents/document/ arms-a-52-298.php.

30. United Nations Security Council (UNSC). (2001). Report of the United Nations Conference on the illicit trade in small arms and light weapons in all its aspects (UN Documents: Security Council Report A/CONF.192/15). United Nations.

31. United Nations Security Council (UNSC). (2013). Final report of the Panel of Experts to the Libya 1970 Sanctions Committee pursuant to resolution 2040 (S/2013/99). UN. 
Retrieved from https://www.securitycouncilreport.org/un-documents/document/ s201399.php.

32. United Nations Security Council (UNSC). (2014a). United Nations Security Council briefing on the Report of the Secretary-General on Libya. (UN Documents: Security Council Report S/PV.7130; p. 8). United Nations. Retrieved from https://www.security councilreport.org/un-documents/document/spv7130.php

33. United Nations Security Council (UNSC). (2014b). Final report of the Panel of Experts assisting the 1970 Libya Sanctions Committee. (UN Documents S/2014/106; Sanctions Committee Documents, p. 97). UN. Retrieved from https://www.securitycouncilreport. org/un-documents/document/s2014106.php.

34. United Nations Security Council (UNSC). (2019). Letter dated 29 November 2019 from the Panel of Experts on Libya established pursuant to Resolution 1973 (2011) addressed to the President of the Security Council. UN. Retrieved from https://digitallibrary.un.o $\mathrm{rg} / \mathrm{record} / 3838591$.

35. Vest, N. (2019, December 13). Can anything stop the flow of advanced weapons into Libya? Defense One. Retrieved from https://www.defenseone.com/ideas/2019/12/ can-anything-stop-flow-advanced-weapons-libya/161892/.

36. Wendt, A. (1992). Anarchy is what states make of it: The social construction of power politics. International Organization, 46(2), 391-425.

37. Wilkins, H. (2020, January 29). Why African countries seek greater role in Libya peace process. Al Jazeera. Retrieved from https://www.aljazeera.com/news/2020/1/29/ why-african-countries-seek-greater-role-in-libya-peace-process. 